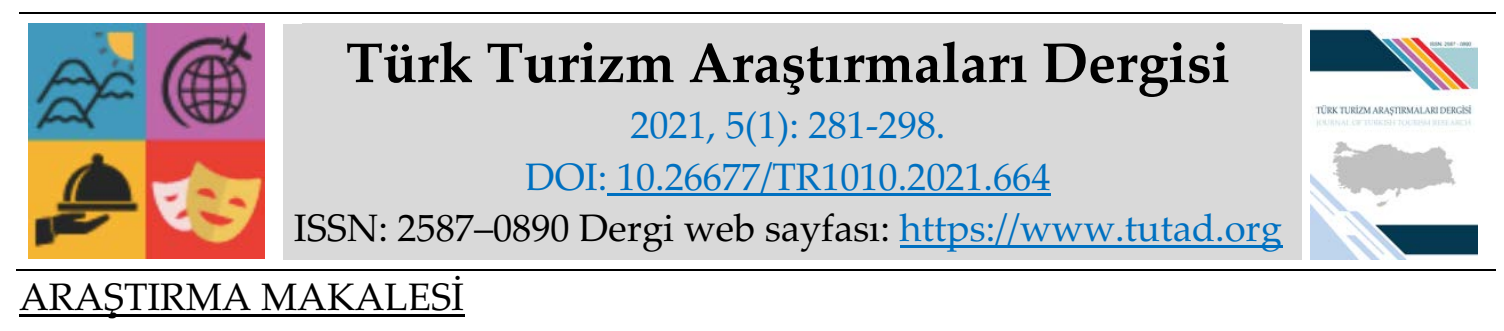

\title{
Kültür Turistlerinin Seyahat Harcamalarına Yönelik Bir Araştırma: Bergama Antik Kenti Örneği*
}

Dr. Öğr. Üyesi Seda SÜER, İzmir Katip Çelebi Üniversitesi, Turizm Fakültesi, İzmir, e-posta: seda.suer@ikc.edu.tr

ORCID: https://orcid.org/0000-0002-0264-071X

Gülsüm SADIK, Yüksek Lisans Öğrencisi, İzmir Kâtip Çelebi Üniversitesi, Sosyal Bilimler Enstitüsü, İzmir, e-posta:gulsumsadik@hotmail.com

ORCID: https://orcid.org/0000-0001-6082-3285

Öz

Günümüzde kültür turistleri turizmin on iki aya yayılmasında çok önemli bir öğe olarak kabul edilmektedir. Kültür turistlerinin seyahat harcamaları ekonomik büyümeye katkı sağlamaktadır. Kültür turistlerinin seyahat harcamalarının incelenmesi bu bakımdan oldukça önemlidir. Bu çalışmada Bergama Antik Kenti'ni ziyaret eden yerli ve yabancı kültür turistlerinin sosyoekonomik, sosyo-demografik, seyahat ile ilgili ve psiko-grafik değişkenlere göre toplam seyahat harcamaları arasındaki farkların incelenmesi amacıyla çeşitli hipotezler geliştirilmiştir. Hipotezlerde test edilen bağımsız gruplar; cinsiyete, uyruğa, seyahatte başkalarının masraflarının karşılanmasına ve yapılan masrafları başka yerde harcamış olma isteğine göre belirlenmiştir. T-testi sonuçlarına göre bağımsız gruplar ile toplam seyahat harcama ortalamaları arasında anlamlı farklılık bulunmaktadır. Çalışmada ayrıca hane halkı gelir düzeylerine göre toplam seyahat harcamalarında farklılığın incelenmesi için ANOVA varyans analizi uygulanmıştır. Hane halkı gelir grupları incelendiğinde üçüncü grubun, birinci ve ikinci gruplara göre daha fazla harcama yaptığı tespit edilmiştir. Bu sonuçlara göre hane halkı gelirinin seyahat harcamaları üzerinde etkisi bulunmaktadır.

* Bu makale, İzmir Kâtip Çelebi Üniversitesi, Sosyal Bilimler Enstitüsü Turizm İşletmeciliği ABD'da yürütülen, "Kültürel Mirasın Turizm Açısından Ekonomik Değerinin Belirlenmesi: Bergama Çok Katmanlı Peyzaj Alanı Çalışması" adlı yüksek lisans tezinden üretilmiştir.

Anahtar Kelimeler: Kültür Turizmi, Turist Harcamaları, Bergama Antik Kenti.

Makale Gönderme Tarihi: 02.09.2020

Makale Kabul Tarihi: 01.03.2021

\section{Önerilen Atıf:}

Süer, S. ve Sadık, G. (2021). Kültür Turistlerinin Seyahat Harcamalarına Yönelik Bir Araştırma: Bergama Antik Kenti Örneği, Türk Turizm Araştırmaları Dergisi, 5(1): 281-298.

(C) 2021 Türk Turizm Araştırmaları Dergisi. 


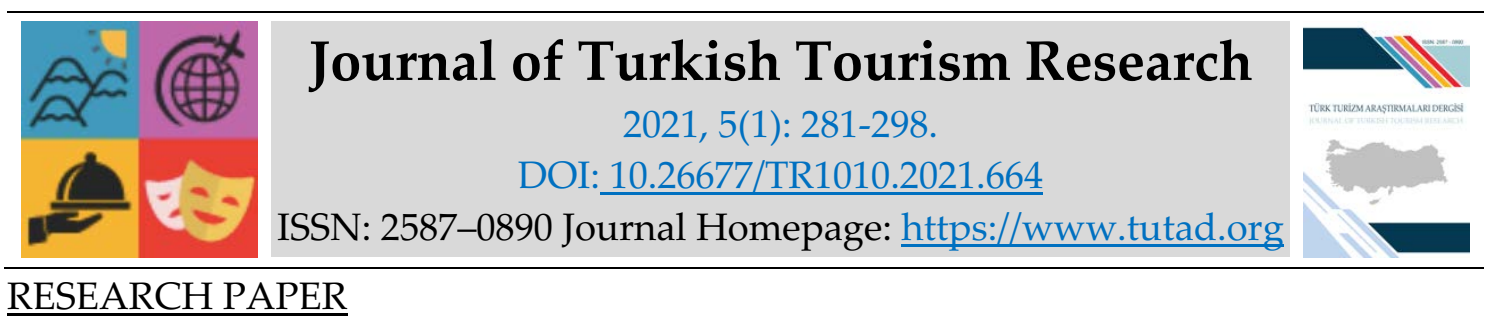

\title{
A Research on The Travel Expenditures of Cultural Tourists: The Case of Pergamon Ancient City
}

Assistant Prof. Dr. Seda SÜER, İzmir Katip Çelebi University, Faculty of Tourism, İzmir, e-mail: seda.suer@ikc.edu.tr

ORCID: https://orcid.org/0000-0002-0264-071X

Gülsüm SADIK, MSc. Student, İzmir Kâtip Çelebi University, Social Sciences Institute, İzmir, email:gulsumsadik@hotmail.com

ORCID: https://orcid.org/0000-0001-6082-3285

\begin{abstract}
Nowadays, Today, cultural tourists are considered as a vital element in the spread of tourism to twelve months. Travel expenditures of cultural tourists contribute to economic growth. In this respect, it is very important to examine the travel expenses of cultural tourists. In this study, various hypotheses are developed in order to examine the differences between the total travel expenditures of local and foreign cultural tourists visiting the Pergamon Ancient City according to socio-economic, socio-demographic, travel-related and psycho-graphic variables. Independent groups tested in hypotheses are determined by gender, nationality, and willingness to pay for the travel expenses of others and to have spent the expenses elsewhere. According to t-test results, there is a significant difference between independent groups and total travel expenditure averages. ANOVA analysis of variance was also applied in the study to examine the difference in total travel expenditures according to household income levels. As the household income groups are examined, it is determined that the third group spends more than the first and second groups. According to these results, household income has an effect on travel expenses.
\end{abstract}

Keywords: Cultural Tourism, Tourist Expenditures, Pergamon Ancient City.

Received: 02.09.2020

Accepted: 01.03.2021

Suggested Citation:

Süer, S. and Sadık, G. (2021). A Research on The Travel Expenditures of Cultural Tourists: The Case of Pergamon Ancient City, Journal of Turkish Tourism Research, 5(1): 281-298.

(c) 2021 Türk Turizm Araştırmaları Dergisi. 


\section{Gíriş}

Turizm sektörü; teknolojik gelişmeler, yeni iş modelleri, uygun seyahat maliyetleri ve vize kolaylığı sayesinde ekonomik olarak en hızlı gelişen sektör haline gelmiştir. Dünya Turizm Örgütü'nün (UNWTO) raporuna göre, uluslararası seyahatlere katılan kişi sayısının 2019 yılında bir önceki yıla göre \%4 artış göstererek 1,5 milyara, uluslararası turizmden elde edilen gelir ise 1,48 trilyon dolara ulaşmıştır (www.e-unwto.org). Bu verilerle turizm sektörü dünyadaki en fazla kazanç sağlayan ilk beş sektör arasında yer almaktadır (www.e-unwto.org). Türkiye İstatistik Kurumu (TUiK) raporuna göre, Türkiye'yi 2018 yılında 45,6 milyon turist ziyaret etmiş ve toplam turizm geliri 29.512.926 \$, kişi başı ortalama harcamalarının ise 647 \$ olduğu belirtilmektedir. 2019 yılında ise Türkiye'yi 51,8 milyon turist ziyaret etmiştir. Türkiye turizm geliri bir önceki yıla göre \%17 artarak 34.520.332 \$'a yükselmiştir. Kişi başı ortalama harcama ise 666 \$ olduğu belirtilmektedir (www.tuik.gov.tr). Bütün bu veriler, turizmin Türkiye'de ve dünyadaki ekonomik etkisini göstermektedir.

Turizm endüstrisinde rekabet üstünlüğü sağlamak ve turizmden daha fazla kazanç elde etmek isteyen destinasyonların turizm ürün ve hizmetlerini çeşitlendirmesi gerekmektedir. Turistik ürün çeşitlerinden biri olan kültür turizmi tüm dünyada artmaktadır. Kültür turizmi, insanların kendi kültürlerini veya diğer kültürleri merak etmek, görmek ve tanımak istemeleri; aynı zamanda kültürler arası etkileşim kurma ihtiyacından dolayı ortaya çıkan bir turizm türüdür. Ayrıca, kültür turizmi, turistlerin görgüsünü ve bilgisini arttıran, araştırma yapmalarını sağlayan, gidilen bölgedeki kasaba, köy, folklorik yapı, el sanatları, yerleşim şekilleri gibi değerleri tanımalarını sağlayan turizm türüdür (Albayrak, 2013: 51-52). Kültür turizmi, kültürel mirasın korunmasını desteklemek, kültürel ifadeleri ve ekonomik gelişimi korumak için önemli bir itici güç olarak görülmektedir (www.e-unwto.org). Kültür turizmi, tarihi ve kültürel kaynakları turizm amaçlı kullanarak ekonomik canlanmayı sağlayan önemli bir unsur haline gelmiştir. Destinasyonlar turist çekmek ve turizmden daha fazla gelir elde etmek için sahip oldukları kültürel ve tarihi alanları kültür turizmine kazandırarak mevcut kullanımlarının arttırılması için çalışmalar yapmaktadır.

Türkiye dünyada kültür turizmi açısından çok zengin ülkelerden biridir. Çünkü, Türkiye bulunduğu coğrafi konum sebebiyle yüzyıllar boyunca pek çok medeniyete ev sahipliği yapmıştır. Dolayısıyla, ülkemizde farklı kültürlerin izlerine rastlanmakta, birçok kalıntı ve kültürel miras varlıkları bulunmaktadır. Bu varlıkların bazıları UNESCO Dünya Miras Listesi'ne alınmıştır. Bunlardan biri de Bergama Antik Kenti'dir. 2014 yılında Çok Katmanlı Peyzaj Alanı olarak 999.uncu UNESCO Dünya Mirası olarak kabul edilen Bergama Antik Kenti önemli bir tarih, kültür ve turizm kentidir. Bergama; 8.500 yıllık tarihi geçmişe sahip, birçok uygarlığa ev sahipliği yapmış, dünyanın en eski yerleşimlerinden birisidir. Bergama'nın sahip olduğu kültürel mirasın korunarak sürdürülmesi hem ülkemiz hem de Dünya kültür mirasının sürdürülebilirliği için büyük önem taşımaktadır. Bergama'yı 2019 yılında yerli ve yabancı olmak üzere toplam 393.376 turist ziyarete gelmiştir. Bir önceki yılda toplam turist sayısı 305.710 olup, turistlerden elde edilen toplam gelir ise 2.672.592.00 TL. olmuş̧tur (www.berto.org.tr).

Turizmden elde edilen gelir, turist harcamalarından sağlanmaktadır. Turist harcamaları ekonomik büyümeye önemli katkı sağlamaktadır. Turist harcamaları, o bölgede yaşayan bireylerin gelirlerini artırmaktadır. Aynı zamanda yurtdışından sağlanan turist akışı, ülkeye giren döviz miktarını artırır ve ödemeler dengesini iyileştirici etkide bulunur. Turist harcamalarının bu gibi etkilerinden dolayı turistlerin seyahat harcamalarının incelenmesi oldukça önemlidir. Bu çalışmada Bergama Antik Kenti'ni kültürel amaçlarla ziyaret eden yerli ve yabancı turistlerinin sosyo-ekonomik, sosyo-demografik, seyahat ile ilgili ve psiko-grafik bilgilerine göre toplam seyahat harcamaları arasındaki farkların incelenmesi amaçlanmıştır. 
Çalışmada kültür turistlerinin toplam harcamalarını; ulaşım harcamaları, konaklama harcamaları, yiyecek-içecek harcamaları, giriş ücreti, hediyelik eşya harcamaları, otopark ücreti ve diğer harcamaların toplamı oluşturmaktadır.

\section{KAVRAMSAL ÇERÇEVE}

Destinasyonlar turizmden daha fazla gelir elde etmek ve rekabet üstünlüğü sağlamak için turistik ürün ve hizmetlerini çeşitlendirmişlerdir. Bunun sonucu olarak alternatif turizm ortaya çıkmıştır. Alternatif turizm; kaynakların azalması, turizmi tüm yıla yaymak, turistlerin klasik turizm anlayışından sıkılarak farklı arayışlara girmeleri, turizmin sürdürülebilirliğinin sağlanması gibi sebeplerden ortaya çıkmıştır (Uygur ve Baykan, 2007: 32). Kültür turizmi en önemli alternatif turizm türlerinden biridir. Hausmann (2007) kültür turizmini, ev sahibi topluluğun dişından insanların, belirli bir destinasyonun kültürel değerlerini ziyaret etmeleri olarak tanımlarken, Silberberg (1995), ev sahibi topluluk dışındaki kişilerin bir topluluk, grup ya da kuruluşun tarihsel, sanatsal, bilimsel, kültürel miras veya yaşam tarzı sunumlarına olan merak ile tamamen veya kısmen motive edilmeleriyle yaptıkları ziyaretler olarak tanımlamıştır. Kültür turizminin faaliyet kapsamını kültürel etkinlikler belirlemektedir. Bir bölgenin coğrafyası, tarihi, gelenek ve görenekleri, giyim kuşamı gibi özelliklerini tanımak için yapılan faaliyetler kültür turizmi kapsamina girmektedir (Haberal, 2011: 32).

Turizmin öznesi insandır ve turizm gelirlerinin kaynağını seyahat eden turistlerin bireysel harcamaları oluşturmaktadır (Hayta, 2008: 39). Harcama, turistlerin tüketim davranışını anlamaya yardımcı olan önemli bir faktör olarak kabul edilmektedir (Legoherel ve Wong, 2006). Kendi ülkesi içinde veya dışında bulunan bir bölgeyi kültür amacıyla ziyaret eden ve farklı kültürleri keşfetme, tanıma isteği ile seyahat eden turistlere kültür turisti denir (Özdamar, 2011: 26). Silberberg (1995), kültür turizmine katılan turistlerin gelir ve eğitim düzeylerinin daha yüksek olduğunu, ziyaret edilen bölgede daha fazla kaldıklarını ve daha fazla harcama yaptıklarını ifade etmektedir. Turist harcamaları hem ulusal hem de bölgesel düzeylerde ekonomik büyümeye önemli katkı sağlamaktadır. Turist harcamaları ve değişkenleri literatürde yaygın olarak makro perspektiften incelenmiştir ve bu çalışmaların genel amacı turizmin ekonomik etkisini değerlendirmektir. Öte yandan, mikro perspektif düzeyinde turist harcamalarının analizi daha az ilgi görmüştür. Bu nedenle, hangi faktörlerin turist tüketimi kararlarını etkilediğini belirlemek ve bu faktörlerin uygun ekonometrik araçları kullanarak turist harcamaları üzerindeki etkisini ölçmek son derece önemlidir (Marrocu vd., 2015).

Literatür incelemesinde, yerli ve yabancı çalışmalarda bulunan benzer bağımlı ve bağımsız değişkenler, kullanılan analiz yöntemleri ve elde edilen sonuçlar birlikte değerlendirilmiştir. Bu değerlendirmeye göre; öncelikle bağımlı değişkenlerin bazı çalışmalarda birden fazla olduğu görülmektedir (Dardis vd., 1994; Nicolau ve Mas, 2005; Wu vd., 2013). Örneğin; Dardis vd., (1994) çalışmasında bağımlı değişkenleri; aktif boş zaman, pasif boş zaman ve sosyal eğlenceye yapılan hane halkı harcamaları olarak belirlemiştir. Tobit modelinin kullanıldığı çalışmada bağımsız değişkenler ise gelir, aile yaşam döngüsü değişkenleri (hane halkı reisinin yaşı ve medeni durumu, yetişkin sayısı ve çocuk sayısı), hane halkı reisinin eğitim ve ırkı, evin konumudur. Çalışmanın sonucunda harcamalar; gelir, cinsiyet, hane halkı sayısı ve eğitim ile pozitif yönlü; hane halkı reisinin yaşı, ırkı ve medeni durumu ile negatif yönlü ilişkili olduğu belirlenmiştir.

Bağımlı değişkenlerin birden fazla olduğu bir diğer çalışmada Nicolau ve Mas (2005) tatil yapma kararı ve turist harcamalarını etkileyen değişkenleri tespit etmeyi amaçlamışlardır. Heckit modelinin kullanıldığı çalışmada tatil yapma kararını etkileyen değişkenler; gelir, hane halkı büyüklüğü, eğitim, merkez şehrin büyüklüğü ve tatile gitme fikridir. Harcama seviyesini etkileyen belirleyici değişkenler; başlangıç noktası ve varış yeri arasındaki mesafe, konaklama, 
gelir, hane halkı büyüklüğü, yaş, medeni hal ve kalış süresidir. Çalışmanın sonucunda, gelirin ve evli olmanın tatile çıkma kararı ve harcama ile pozitif yönlü, hane halkı büyüklüğünün negatif yönlü olduğu; eğitimin ise tatile gitme eğilimi ile ilişkiliyken harcama düzeyinin belirleyicisi olmadığı belirtilmiştir. Benzer bir çalışmada, Wu vd., (2013) seyahat seçimi ile harcama düzeyinin güçlü bir şekilde ilişkili olduğunu scobit modeli kullanarak analiz etmişlerdir. Bununla birlikte, seyahat etme seçiminin eğitim ve gelirden olumlu etkilenirken, cinsiyet ve hane halk1 büyüklüğünden olumsuz etkilendiği belirtilmiştir. Ayrıca, turist harcama seviyesinin de hane büyüklügünden olumsuz; gelir ve seyahat mesafesine göre ise olumlu etkilendiğini tespit edilmiştir. Çalışmada tüm tatil için toplam harcama dikkate alındığından; seyahat mesafesinin olumlu etkisi muhtemelen seyahat maliyetlerinden ve kalış süresinden kaynaklanmaktadır.

Ancak literatürde çoğunlukla turist harcamalarının analizinde tek bağımlı değişkenin kullanıldığı ve bu değişkeni açıklayan bağımsız değişkenlerin araştırıldığı görülmektedir. Yazarların çoğu bağımlı değişkeni, genellikle logaritmik dönüşümle elde edilen kişi başına harcamaların değeri olarak tanımlamaktadır. Literatürde, bağımsız değişkenler dört ana kategoride gruplanabilir. Bunlar; sosyo-ekonomik (Agarwal ve Yochum, 1999; Nicolau ve Mas, 2005; Zheng ve Zhang, 2011; Hung vd., 2012; Garcia-Sanchez vd., 2013; Marrocu vd., 2015; Tavares vd., 2015; Topbaş ve Uğuz, 2017; Daşkıran ve Özkoç, 2019), sosyo-demografik (Jang vd., 2004; Nicolau ve Mas, 2005; Hung vd., 2012; Marrocu vd., 2015; Serra vd., 2015; Jurdana ve Frleta, 2016; Topbaş ve Uğuz, 2017; Daşkıran ve Özkoç, 2019), seyahatle ilgili (Agarwal ve Yochum, 1999; Seiler vd., 2003; Jang vd., 2004; Nicolau ve Mas, 2005; Garcia-Sanchez vd., 2013; Marrocu vd., 2015; Tavares vd., 2015; Jurdana ve Frleta, 2016) ve psiko-grafik (Oppermann, 1996; Nicolau ve Mas, 2005; Garcia-Sanchez vd., 2013; Marrocu vd., 2015; Serra vd., 2015; Tavares vd., 2015) değişkenlerdir. Söz konusu çalışmalarda kullanılan bağımlı değişkenlere ve metodolojiye bağlı olarak farklı bulgular elde edilmiştir. Örneğin; Oppermann (1996) ilk kez ile tekrar gelen ziyaretçiler arasındaki seyahat harcama farklılıklarını araştırdığı çalışmasında hipotezlerin testinde iki örnek t-testini kullanmıştır. Çalışmanın bulgularına göre tekrar gelen ziyaretçilerin günlük harcamaları ilk kez gelen ziyaretçilere göre daha düşüktür.

Literatürde tartışılan bir diğer önemli konu, ampirik metodolojide turist harcamaları ile bağımsız değişkenler arasındaki ilişkinin analizinde kullanılan tanımlayıcı istatistiklerden ekonometrik modellere kadar birçok farklı yaklaşımla ilgilidir. Yerli ve yabancı çalışmalar incelendiğinde çoğunlukla regresyon modellerinin uygulandığı görülmüştür. Standart bir regresyon yöntemi olan sıradan en küçük kareler (SEKK) yöntemi bunlardan en çok kullanılandır. Bu yöntemin kullanıldığı çalışmalarda sosyo-ekonomik (Garcia-Sanchez vd., 2013; Hung vd., 2012; Tavares vd., 2015), sosyo-demografik (Jang vd., 2004; Hung vd., 2012; Serra vd., 2015), seyahate ilişkin (Jang vd., 2004; Garcia-Sanchez vd., 2013; Tavares vd., 2015) ve psiko-grafik değişkenlerin (Marrocu vd., 2015; Serra vd., 2015; Tavares vd., 2015) seyahat harcamaları üzerine etkileri incelenmiştir. Bu çalışmaların önemli bulgularına göre; gelirin (Jang vd., 2004), yaşın (Jang vd., 2004; Hung vd., 2012), eğitimin (Hung vd., 2012; Garcia-Sanchez vd., 2013), arkadaşla seyahat etmenin (Jang vd., 2004; Garcia-Sanchez vd., 2013), kalış süresinin (Jang vd., 2004; Tavares vd., 2015), ilk ziyaretin (Jang vd., 2004; Garcia-Sanchez vd., 2013), konaklama türünün (GarciaSanchez vd., 2013; Serra vd., 2015) ve turist motivasyonlarını (Serra vd., 2015; Tavares vd., 2015) seyahat harcamalarıyla pozitif yönlü ilişkili bulunmasıdır.

Yarı logaritmik ve çarpımsal modelin kullanıldığı başka bir çalışmada (Agarwal ve Yochum, 1999) turist harcamaları gelirle pozitif yönlü, çocuk sayısı ile negatif yönlü ilişkili bulunmuştur. Yapısal eşitlik modelinin uygulandığı diğer bir çalışma ise (Seiler vd., 2003) kalış süresi ve seyahat grubu büyüklüğünün seyahat harcamaları ile pozitif ilişkili olduğunu göstermektedir. Ancak, kantil regresyon modelinin kullanıldığı çalışmada (Marrocu vd., 2015) grup büyüklügünün seyahat harcamaları ile negatif ilişkili olduğu bulunmuştur. Çoklu regresyon 
(Jurdana ve Frleta, 2016) ve lojistik regresyon (Topbaş ve Uğuz, 2017) modellerinin kullanıldığ çalışmalarda gelirin turist harcamalarıyla ilişkisinin pozitif yönlü olduğu belirtilmiştir. Tobit modelinin uygulandığı çalışmalarda (Dardis vd., 1994; Zheng ve Zhang, 2011; Daşkıran ve Özkoç, 2019) sosyo-ekonomik özelliklerin seyahat harcamalarına etkileri incelenmiştir. Bu çalışmaların bulguları değerlendirildiğinde bağımsız değişkenler farklılık gösterse de her üç çalışmanın ortak bulgusu gelir düzeyi ile seyahat harcamaları arasında pozitif yönlü bir ilişkinin bulunmasıdır. Bunun yanında, eğitim (Dardis vd., 1994; Zheng ve Zhang, 2011) ve cinsiyet (Dardis vd., 1994; Daşkıran ve Özkoç, 2019) değişkenleri de turist harcamaları ile pozitif yönlü ilişkili bulunmuştur.

Sonuç olarak; turist harcamalarının değişkenleri üzerine yapılan çalışmalarda, 4 temel belirleyici değişken kullanılmıştır. Bunlar; sosyo-ekonomik, sosyo-demografik, seyahate ilişkin ve psikografik değişkenlerdir. Çalışmalarda; sosyo-ekonomik (gelir, hane halkı geliri, konut kredi giderleri, tıbbi ve sağlık giderleri, refah göstergeleri, ev ve araç sahipliği), sosyo-demografik (yaş, cinsiyet, eğitim, mesleki durum, uyruk, yetişkin sayısı, çocuk sayısı), seyahat ile ilgili (kalış süresi, seyahat grubundaki kişi sayısı, destinasyon sayısı, kullanılan konaklama ve ulaşım türü, seyahat süresi, başlangıç noktası ile varış noktası arasındaki mesafe) ve psiko-grafik (tekrarlanan davranış ve yolculuk motivasyonu, tatile çıkma fikri, arkadaş veya akraba ziyareti, destinasyonun görüntüsü, farklı aktiviteler) değişkenlerin turist ve seyahat harcamaları üzerine etkileri incelenmiştir. Turizm çalışmalarındaki en dikkat çeken konulardan biri, destinasyonlara etkileri ve pazarlama stratejilerinin sonuçları göz önüne alındığında, turist harcama kararlarını yönlendiren faktörlerin analizidir. Bu bakımdan, turistlerin harcama davranışı üzerine yapılan çalışmaların iki önemli katkısı bulunmaktadır. Birincisi, bir dizi değişkenin harcama seviyeleri üzerindeki rolünü değerlendirirken, ikincisi harcama kararını etkileyen faktörlerin araştırılmasıdır (Brida ve Scuderi, 2012: 2-3). Turist harcamalarının hesaplanmasında kullanılan en yaygın yöntem alan araştırmalarıdır. Yöntemin hesaplama şekli, seçilen örnek grup ya da gruplarla seyahatleri süresince yapmış oldukları harcamalarına ilişkin anketlerin uygulanmasıdır (Frechtling, 1994: 368). Literatür incelemesi sonucunda, bu çalışmada turist harcamalarının analizinde kullanılan yöntemlerden biri olan hipotezlerin testinde iki örnek t-testi kullanılarak, farklı gruplar arasındaki harcamaların ortalamalarına ilişkin farklılıkların tespit edilmesi amaçlanmıştır.

\section{YÖNTEM}

Çalışmada, sosyo-ekonomik, sosyo-demografik, psiko-grafik özelliklere ve seyahate ilişkin bilgilere göre gruplanmış yerli ve yabancı kültür turistlerinin toplam seyahat harcamaları incelenmiştir. Bu çalışmada kullanılacak veriler, nicel araştırma tekniklerinden yüz yüze anket tekniği uygulanarak elde edilmiştir. Ziyaretçilere yüz yüze uygulanan anketler; kültür turistlerinin sosyo-ekonomik, sosyo-demografik, psiko-grafik özellikleri ile seyahat ve harcamalarına ilişkin bilgilerini elde etmeye yönelik soruları içermektedir. Kültür turist gruplarının toplam seyahat harcamalarını inceleme amacıyla geliştirilen hipotezler nicel verilerin analizinde sıkça kullanılan SPSS 25.0 programından faydalanılarak bulgular elde edilmiştir.

$\mathrm{Bu}$ çalışmada, kültür turistlerinin toplam harcamalarına göre oluşturulan bağımsız gruplar arasında toplam harcama farklarını ortaya koymak için hipotezler geliştirilmiştir. Öncelikle toplam seyahat harcama verilerinin normal dağılımı incelenmiştir. Daha sonra turistlerin demografik özelliklerine göre belirlenmiş grupların ortalaması ile toplam seyahat harcamaları arasındaki farkları analiz etmek için çeşitli hipotezler geliştirilmiştir. Bu hipotezlerde test edilen bağımsız gruplar; cinsiyete, uyruğa, seyahatte başkalarının masraflarının karşılanmasına ve yapılan masrafları başka yerde harcamış olma isteğine göre belirlenmiştir. Geliştirilen 
hipotezlerin analizinde bağımsız iki örnek t-testi kullanılmıştır. Çalışmada ayrıca hane halkı gelir düzeylerine göre toplam seyahat harcamalarında bir fark olup olmadığını incelemek için ANOVA varyans analizi uygulanmıştır. Bu çalışmada bulunan hipotezler aşağıda listelenmiştir:

$\mathrm{H}_{1}$ : Kadın ve erkeklerin toplam seyahat harcamalarının ortalamaları arasında anlamlı bir fark vardir.

$\mathrm{H}_{2}$ : Yerli ve yabancı turistlerin toplam seyahat harcamalarının ortalamaları arasında anlamlı bir fark vardır.

$\mathrm{H}_{3}$ : Seyahatte başkalarının masraflarını karşılayan ve karşılamayanların toplam seyahat harcamalarının ortalamaları arasında anlamlı bir fark vardır.

$\mathrm{H}_{4}$ : Parayı başka yerde harcamış olmayı isteyen ve istemeyenlerin toplam seyahat harcamalarının ortalamaları arasında anlamlı bir fark vardır.

H5: Hane halkı gelir düzeyleri arasında toplam seyahat harcamalarının ortalamaları arasında anlamlı bir fark vardır.

\section{Veri Seti ve Örneklem}

Bergama Antik Kenti'ni 2019 yılı Ağustos ayında 12.311 yerli turist, 10.012 yabancı turist olmak üzere toplam 22.323 kişi ziyaret etmiştir. Çalışmanın örneklemini, basit tesadüfi örnekleme yöntemi ile seçilen ziyaretçiler oluşturmaktadır. Evrendeki kişi sayısı bilindiği için aşağıdaki formül kullanılarak örneklem büyüklüğü elde edilmiştir (Özdemir vd., 2015: 159).

$$
n=\frac{N * t^{2} * p * q}{d^{2} * N+t^{2} * p * q}
$$

N: Hedef kitledeki birey sayısı (22.323 yıllık ziyaretçi),

n: Örnekleme alınacak birey sayısı,

p: İncelenen olayın görülüş sıklığı (gerçekleşme olasılı̆̆ı $\% 50$ olarak kabul edilmiştir),

q: İncelenen olayın görülmeyiş sıklığı (1-p),

$\mathrm{t}$ : Belirli bir anlamlılık düzeyinde, $\mathrm{t}$ tablosuna göre bulunan teorik değer (\%95 güven düzeyinde $\mathrm{t}=1,96)$,

d: Olayın görülüş sıklığına göre kabul edilen \pm örnekleme hatasını ifade etmektedir (genellikle \% 4 kullanılmaktadır).

$\mathrm{Bu}$ formüle göre gerekli örneklem sayısı $\mathrm{n}=371$ olarak hesaplanmaktadır. Çalışma için gerekli verilerin toplanması amaciyla Ağustos 2019 döneminde 400 kişiyle yüz yüze görüşülerek anket yapılmıştır. Araştırma için Bergama Antik Kenti içindeki en çok ziyaretçi çeken noktalar tercih edilmiştir. Anket çalışması, Akropol, Asklepion, Kızılavlu (Bazilika) ören yerlerinde ve Bergama müzesinde gerçekleştirilmiştir.

\section{Demografik Verilerin Analizi}

$\mathrm{Bu}$ çalışmada öncelikle kültür turistlerinin sosyo-demografik ve seyahate ilişkin verilerinin analizi gerçekleştirilmiştir. Bu analizlere göre; Bergama Antik Kenti'ni 2019 Ağustos ayında kültürel amaçlarla ziyaret eden 400 yerli ve yabancı turistin 213 'ünü $(\% 53,3)$ erkeklerin, 187'sini $(\% 46,8)$ kadınların oluşturduğu tespit edilmiştir. Çalışmada, ankete katılan yerli ve yabancı turistler bulunmaktadır. Yapılan analize göre; turistlerin 330'u $(\% 82,5)$ yerli ve $70^{\prime} \mathrm{i}(\% 17,5)$ yabancıdır. Turistlere seyahate beraber gelerek masraflarını karşıladıkları kişiler olup olmadığı 
sorulmuştur. Turistlerin 217'si (\%54,5) başkalarının masraflarını karşılamışlardır, 183'ü $(\% 45,75)$ ise başkalarının masraflarını karşılamamışlardır. Turistlere Bergama Antik Kenti'nde harcadığ parayı başka yerde harcamış olmayı tercih edip etmedikleri sorulduğunda turistlerin $329^{\prime} \mathrm{u}$ $(\% 82,25)$ hayır cevabını vermiş, $71^{\prime} i(\% 17,75)$ evet cevabını vermiştir. Turistlerden hane halkı gelirleri hakkında bilgi verilmesi istenmiştir. Hane halkı gelirlerine yönelik yapılan analize göre; turistlerin çoğunun yani 195 'inin $(\% 48,8)$ hane halkı geliri 6.501-9.500 TL olduğu bulunmuştur. Hane halkı gelirlerine ilişkin oranlar sırasıyla 74'ünün (\% 18,5) 4.501-6.500 TL 46'sının (\%11,5) 3001-4500 TL 28'inin (\% 7,0) 1.501-3.000 TL 23'ünün $(\% 5,8) 37.501$ TL ve daha fazlası, 13'ünün (\%3,3) 9.501-19.000 TL 11'inin (\% 2,8) 28.501-37.500 TL 10'unun (\% 2,5) 19.001-28.500 TL olduğu tespit edilmiştir.

\section{BULGULAR}

Bu çalışmada, seyahate ilişkin elde edilen toplam seyahat harcama verileri ile ilgili çeşitli hipotezler oluşturulmuştur.

Bu hipotezler kültür turistlerinin sosyo-ekonomik, sosyo-demografik, psiko-grafik ve seyahate ilişkin verilerine göre oluşturulan grupların toplam seyahat harcamaları ortalamalarına göre farklarını ortaya koymak amacıyla geliştirilmiştir. Bu hipotezlerin test edilmesinden önce toplam seyahat harcamalarına normallik testi uygulanmıştır. Normallik testi sonucunda toplam seyahat harcamalarının şiddetli pozitif çarpık olduğu anlaşılmıştır. Toplam seyahat harcama verilerini normalize etmek için logaritmik dönüşüm uygulanmıştır. Normallik testinde gözlem sayısı 29 'dan az olduğunda Shapiro-Wilks testi, gözlem sayısı 29 ve daha büyük olduğunda ise, Kolmogorov-Smirnov (Lilliefors) testi kullanılmaktadır (Kalaycı, 2018:10, 53-55). Veri sayısı 400 olduğu için analizde Kolmogorov-Smirnov (Lilliefors) testi kullanılmıştır. Bu testin sıfır $\left(\mathrm{H}_{0}\right)$ ve karşıt $\left(\mathrm{H}_{1}\right)$ hipotezleri aşağıda verilmiştir:

Ho: Toplam seyahat harcamaları normal dağılıma sahiptir.

Hı: Toplam seyahat harcamaları normal dağılıma sahip değildir.

Logaritmik dönüşüm sonucunda Kolmogorov-Smirnov testinden elde edilen sonuçlar aşağıdaki tabloda gösterilmiştir.

Tablo 1. Normallik Testi

\begin{tabular}{|l|c|c|c|}
\hline \multirow{2}{*}{ Toplam Seyahat Harcamalar1 } & \multicolumn{3}{|c|}{ Kolmogorov-Smirnov } \\
\cline { 2 - 4 } & Statistic & df & Sig. \\
\hline
\end{tabular}

Kolmogorov-Smirnov testinden elde edilen sonuç değerlendirildiğinde, $\% 5$ anlamlılık düzeyine göre toplam seyahat harcamaları verilerinin $\mathrm{p}$ (sig.) değeri $(0,151) \% 5^{\prime}$ ten büyük olduğu için $\mathrm{H}_{0}$ hipotezi kabul edilir. Yani veriler normal dağılmıştır.

\section{Hipotez Testleri Sonuçları}

Toplam seyahat harcamalarının normal dağılımı test edildikten sonra cinsiyete göre bu harcamalar arasında fark olup olmadığı analiz edilmiştir. İki grubun ortalamaları arasındaki farkın anlamlı olup olmadığı, bağımsız iki örnek t-testi kullanılarak incelenmiştir. İki grubun 
ortalamaları arasında anlamlı bir farklılık olup olmadığını test eden t-testinin hipotezi aşağıdaki gibidir.

$\mathrm{H}_{0}=$ Kadın ve erkeklerin toplam seyahat harcamalarının ortalamaları arasında anlamlı bir fark yoktur.

$\mathrm{H}_{1}=$ Kadın ve erkeklerin toplam seyahat harcamalarının ortalamaları arasında anlamlı bir fark vardir.

Tablo 2. Cinsiyete Göre Toplam Seyahat Harcamalarının Karşılaştırılması

\begin{tabular}{|c|c|c|c|c|c|c|c|c|c|c|c|}
\hline & & & Cinsiyet & $\mathrm{N}$ & \multicolumn{2}{|c|}{ Ortalama } & \multicolumn{2}{|c|}{$\begin{array}{l}\text { Standart } \\
\text { Sapma }\end{array}$} & $\begin{array}{l}\text { Ortalamanin } \\
\text { Standart } \\
\text { Hatası }\end{array}$ & & \\
\hline & \multirow{2}{*}{\multicolumn{2}{|c|}{$\begin{array}{l}\text { Toplam } \\
\text { Seyahat } \\
\text { Harcamaları }\end{array}$}} & Kadın & & & & & 84952 & \multicolumn{3}{|c|}{, 05821 } \\
\hline & & & Erkek & 187 & \multicolumn{2}{|c|}{1,8984} & & 87704 & \multicolumn{3}{|c|}{0,6414} \\
\hline & & \multirow{2}{*}{\multicolumn{2}{|c|}{$\begin{array}{l}\text { Levene's Test } \\
\text { for Equality of } \\
\text { Variences }\end{array}$}} & \multicolumn{8}{|c|}{$\mathrm{t}$ test for Equality of Means } \\
\hline & & & & & & & & & & \multicolumn{2}{|c|}{$\begin{array}{l}\text { \%95 Güven Aralığ1 } \\
\text { Fark1 }\end{array}$} \\
\hline & & $\mathrm{F}$ & Sig. & $\mathrm{t}$ & $\mathrm{df}$ & $\begin{array}{l}\text { Sig } \\
(2- \\
\text { tai }\end{array}$ & ed) & $\begin{array}{l}\text { Ortalama } \\
\text { Fark1 }\end{array}$ & $\begin{array}{l}\text { Standart } \\
\text { Hata } \\
\text { Fark1 }\end{array}$ & Alt Sinir & Üst Sinir \\
\hline \multirow[t]{2}{*}{$\begin{array}{l}\text { Toplam } \\
\text { Seyahat } \\
\text { Harcamalar1 } \\
\end{array}$} & $\begin{array}{l}\text { Equal } \\
\text { variances } \\
\text { assumed } \\
\end{array}$ & ,587 & 444 & $-2,627$ & 398 & ,00 & &,- 22703 & ,08643 &,- 39695 &,- 05712 \\
\hline & $\begin{array}{l}\text { Equal } \\
\text { variances } \\
\text { not } \\
\text { assumed }\end{array}$ & & & $-2,621$ & 387,780 &, 00 & & $\begin{array}{l}-22703 \\
\end{array}$ & ,08661 &,- 39732 & -05675 \\
\hline
\end{tabular}

Levene testi sonuçlarına göre anlamlılık seviyesi 0,05 'den büyük olduğundan iki grubun varyansları homojendir ( $\mathrm{p}$ değeri $=0,444)$. Analiz sonucuna göre 187 erkek katılımcının ortalaması 1,8984 ve 213 kadın katılımcının ortalaması 1,6714'dür. Yani kadınlar erkeklere göre daha az toplam seyahat harcaması yapmıştır. Grupların ortalamaları arasında fark olduğu gözlenmektedir. T-testine göre sig. değerinin $0,05^{\prime}$ den küçük olması ( $\mathrm{p}$ değeri $=0,009$ ) grupların ortalamaları arasında anlamlı bir fark olduğunu göstermektedir. Dolayısıyla sıfır (null) hipotezi reddedilerek, alternatif hipotez kabul edilmiştir. Bu durum karşılaştırılan gruplar arasında anlamlı fark olduğunu göstermektedir.

Çalışmada anketler yerli ve yabancı turistlere uygulanmıştır, dolayısıyla cevaplayıcı iki bağımsız grup bulunmaktadır. Bu bağımsız grupların toplam seyahat harcamalarının arasında anlamlı bir fark olup olmadığı test edilmiştir. İki grubun ortalamaları arasındaki farkın anlamlı olup olmadığı bağımsız iki örnek t-testi kullanılarak incelenmiştir. İki grubun ortalamaları arasında anlamlı bir farklılık olup olmadığını test eden t-testi hipotezi aşağıdaki gibidir.

$\mathrm{H}_{0}=$ Yerli ve yabancı turistlerin toplam seyahat harcamalarının ortalamaları arasında anlamlı bir fark yoktur.

$\mathrm{H}_{2}=$ Yerli ve yabancı turistlerin toplam seyahat harcamalarının ortalamaları arasında anlamlı bir fark vardır. 
Tablo 3. Yerli ve Yabancı Turistlere Göre Toplam Seyahat Harcamalarının Karşılaştırılması

\begin{tabular}{|l|l|r|r|r|r|}
\hline & Turist & N & Ortalama & $\begin{array}{l}\text { Standart } \\
\text { Sapma }\end{array}$ & $\begin{array}{l}\text { Ortalamanin } \\
\text { Standart } \\
\text { Hatası }\end{array}$ \\
\hline $\begin{array}{l}\text { Toplam } \\
\begin{array}{l}\text { Seyahat } \\
\text { Harcamalar1 }\end{array}\end{array}$ & Yerli & 330 & 1,8091 &, 88722 &, 04884 \\
\cline { 2 - 7 } & Yabanc1 & 70 & 2,1286 & 1,12831 &, 13486 \\
\hline
\end{tabular}

\begin{tabular}{|c|c|c|c|c|c|c|c|c|c|c|}
\hline & \multirow{2}{*}{\multicolumn{2}{|c|}{$\begin{array}{l}\text { Levene's Test } \\
\text { for Equality of } \\
\text { Variences }\end{array}$}} & \multicolumn{7}{|c|}{$\mathrm{t}$ test for Equality of Means } \\
\hline & & & & \multirow[b]{2}{*}{$\mathrm{t}$} & \multirow[b]{2}{*}{$\mathrm{df}$} & \multirow[b]{2}{*}{$\begin{array}{l}\text { Sig. } \\
(2- \\
\text { tailed) }\end{array}$} & \multirow[b]{2}{*}{$\begin{array}{l}\text { Ortalama } \\
\text { Fark1 }\end{array}$} & \multirow[b]{2}{*}{$\begin{array}{l}\text { Standar } \\
\text { t Hata } \\
\text { Fark1 }\end{array}$} & \multicolumn{2}{|c|}{$\begin{array}{l}\text { \%95 Güven Aralığ } \\
\text { Farkı }\end{array}$} \\
\hline & & $\mathrm{F}$ & Sig. & & & & & & $\begin{array}{l}\text { Alt } \\
\text { Sinir }\end{array}$ & $\begin{array}{l}\text { Üst } \\
\text { Sinır }\end{array}$ \\
\hline $\begin{array}{l}\text { Toplam } \\
\text { Seyahat } \\
\text { Harcamaları }\end{array}$ & $\begin{array}{l}\text { Equal } \\
\text { variances } \\
\text { assumed }\end{array}$ & 2,624 & , 106 & $-2,601$ & 398 & ,010 &,- 31948 & ,12284 &,- 39695 &,- 56097 \\
\hline & $\begin{array}{l}\text { Equal } \\
\text { variances } \\
\text { not } \\
\text { assumed }\end{array}$ & & & $-2,227$ & 387,969 &, 028 &,- 31948 & 14343 &,- 39732 &,- 60452 \\
\hline
\end{tabular}

Bağımsız gruplar için t-testi tablosuna göre, öncelikle varyansların homojen olup olmadığı incelendiğinde $\mathrm{F}$ değeri varyansların homojenliğini göstermiştir. Levene's testine göre anlamlılık seviyesi 0,05 'den büyük olduğundan iki grubun varyansları homojendir ( $\mathrm{p}$ değeri $=0,106$ ). Analiz sonucuna göre 330 yerli turist cevaplayıcının ortalaması 1,8091 ve 70 yabancı turist cevaplayıcının ortalaması 2,1286'dır. Başka bir ifadeyle, yabancı turistler yerli turistlere göre daha fazla toplam seyahat harcaması yapmıştır. Bağımsız iki örnek t-testine göre grupların ortalamaları arasında fark olduğu gözlenmektedir. $P$ değerinin 0,05 'den küçük olması ( $p$ değeri $=0,010$ ) grupların ortalamaları arasında anlamlı bir fark olduğunu göstermektedir. Dolayısıyla sıfır (null) hipotezi reddedilerek, alternatif hipotez kabul edilmiş olur. Bu durum karşılaştııılan gruplar arasında anlamlı fark olduğunu göstermektedir.

Cevaplayıcılara seyahate beraber gelerek masraflarını karşıladıkları olup olmadığı sorulmuştur. Seyahatte başkalarının masraflarını karşılayan ile karşılamayan iki grup bulunmaktadır. Bu durumda iki bağımsız grup ortaya çıkmaktadır. Bu bağımsız grupların toplam seyahat harcamalarının arasında anlamlı bir fark olup olmadığı test edilmiştir. İki grubun ortalamaları arasındaki farkın anlamlı olup olmadığı bağımsız iki örnek t-testi kullanılarak incelenmiştir. İki grubun ortalamaları arasında anlamlı bir farklılık olup olmadığını test eden t-testi hipotezi aşağıdaki gibidir.

H0: Seyahatte başkalarının masraflarını karşılayan ve karşılamayanların toplam seyahat harcamalarının ortalamaları arasında anlamlı bir fark yoktur.

H3: Seyahatte başkalarının masraflarını karşılayan ve karşılamayanların toplam seyahat harcamalarının ortalamaları arasında anlamlı bir fark vardır. 
Tablo 4. Başkalarının Masraflarını Karşılamaya Göre Toplam Seyahat Harcamalarının Karşılaştırılması

\begin{tabular}{|l|l|r|r|r|r|}
\hline & Masrafları & $\mathrm{N}$ & Ortalama & $\begin{array}{l}\text { Standart } \\
\text { Sapma }\end{array}$ & $\begin{array}{l}\text { Ortalamanın } \\
\text { Standart } \\
\text { Hatası }\end{array}$ \\
\hline $\begin{array}{l}\text { Toplam } \\
\begin{array}{l}\text { Seyahat } \\
\text { Harcamaları }\end{array}\end{array}$ & Karşılayan & 217 & 2,0230 &, 99742 &, 06771 \\
\cline { 2 - 6 } & Karşımayan & 183 & 1,6776 &, 83198 &, 06150 \\
\hline
\end{tabular}

\begin{tabular}{|c|c|c|c|c|c|c|c|c|c|c|}
\hline & \multirow{2}{*}{\multicolumn{2}{|c|}{$\begin{array}{l}\text { Levene's } \\
\text { Test for } \\
\text { Equality of } \\
\text { Variences }\end{array}$}} & \multicolumn{7}{|c|}{$\mathrm{t}$ test for Equality of Means } \\
\hline & & & & \multirow[b]{2}{*}{$\mathrm{t}$} & \multirow[b]{2}{*}{$\mathrm{df}$} & \multirow[b]{2}{*}{$\begin{array}{l}\text { Sig. } \\
(2- \\
\text { tailed }) \\
\end{array}$} & \multirow[b]{2}{*}{$\begin{array}{l}\text { Ortalama } \\
\text { Fark1 }\end{array}$} & \multirow[b]{2}{*}{$\begin{array}{l}\text { Standart } \\
\text { Hata } \\
\text { Fark1 }\end{array}$} & \multicolumn{2}{|c|}{$\begin{array}{l}\text { \%95 Güven } \\
\text { Aralığı Fark1 }\end{array}$} \\
\hline & & $\mathrm{F}$ & Sig. & & & & & & $\begin{array}{l}\text { Alt } \\
\text { Sinir }\end{array}$ & $\begin{array}{l}\text { Üst } \\
\text { Sinir }\end{array}$ \\
\hline $\begin{array}{l}\text { Toplam } \\
\text { Seyahat } \\
\text { Harcamaları }\end{array}$ & $\begin{array}{l}\text { Equal } \\
\text { variances } \\
\text { assumed }\end{array}$ & ,217 & 642 & 3,719 & 398 & ,000 & 34545 & ,09288 & 16285 & $\begin{array}{l}, 528 \\
04\end{array}$ \\
\hline & $\begin{array}{l}\text { Equal } \\
\text { variances } \\
\text { not } \\
\text { assumed }\end{array}$ & & & 3,777 & 397,956 & ,000 & 34545 & ,09147 & ,16562 & $\begin{array}{l}, 525 \\
27\end{array}$ \\
\hline
\end{tabular}

Analiz sonuçlarında Levene's Test of Equality of Variances alanındaki sig değeri $(0,642)$ dağılımların farklılık arz ettiğini göstermektedir. Analiz sonucuna göre 217 kişi seyahatte başkalarının masraflarını karşılamış olanların ortalaması 2,0230 ve seyahatte başkalarının masraflarını karşılamamış olan 183 kişinin ortalaması ise 1,6776'dır. Başka bir ifadeyle, seyahatte başkalarının masraflarını karşılayanlar daha fazla toplam seyahat harcaması yapmıştır. Grupların ortalamaları arasında fark olduğu gözlenmektedir. Sig ( 2 tailed) sonucunda $(p=.000)$ grupların ortalamaları arasında anlamlı bir fark olduğunu göstermektedir (\%95 güven aralığ içinde sig. değeri 0,05'ten küçük çıkmıştır). Dolayısıyla sıfır (null) hipotezi red edilerek, alternatif hipotez kabul edilmiştir.

Cevaplayıcılara Bergama Antik Kenti'nde harcamış oldukları parayı başka bir yerde harcamış olmayı tercih edip etmediği sorulmuştur. Cevaplayıcılar arasında Bergama Antik Kenti'nde harcadığı parayı başka yerde harcamış olmayı tercih eden ve etmeyen iki grup bulunmaktadır. $\mathrm{Bu}$ durumda iki bağımsız grup ortaya çıkmaktadır. Bu bağımsız grupların toplam seyahat harcamalarının arasında anlamlı bir fark olup olmadığı test edilmiştir. İki grubun ortalamaları arasındaki farkın anlamlı olup olmadığı bağımsız iki örnek t-testi kullanılarak incelenmiştir. İki grubun ortalamaları arasında anlamlı bir farklılık olup olmadığını test eden t-testi hipotezi aşağıdaki gibidir.

$\mathrm{H}_{0}=$ Parayı başka yerde harcamış olmayı isteyen ve istemeyenlerin toplam seyahat harcamalarının ortalamaları arasında anlamlı bir fark yoktur.

$\mathrm{H}_{4}=$ Parayı başka yerde harcamış olmayı isteyen ve istemeyenlerin toplam seyahat harcamalarının ortalamaları arasında anlamlı bir fark vardır. 
Tablo 5. Başka Yerde Harcama Tercihlerine Göre Toplam Seyahat Harcamalarının Karşılaştırılması

\begin{tabular}{|l|l|l|l|l|l|}
\hline & Parayı & $\mathrm{N}$ & Ortalama & $\begin{array}{l}\text { Standart } \\
\text { Sapma }\end{array}$ & $\begin{array}{l}\text { Ortalamanin } \\
\text { Standart } \\
\text { Hatası }\end{array}$ \\
\hline $\begin{array}{l}\text { Toplam } \\
\text { Seyahat } \\
\text { Harcamaları }\end{array}$ & $\begin{array}{l}\text { Başka yerde harcamayı } \\
\text { tercih eden }\end{array}$ & 71 & 2,1127 & 1,08955 &, 12931 \\
\cline { 2 - 6 } & $\begin{array}{l}\text { Başa yerde harcamayı } \\
\text { tercih etmeyen }\end{array}$ & 329 & 1,8116 &, 89769 &, 04949 \\
\hline
\end{tabular}

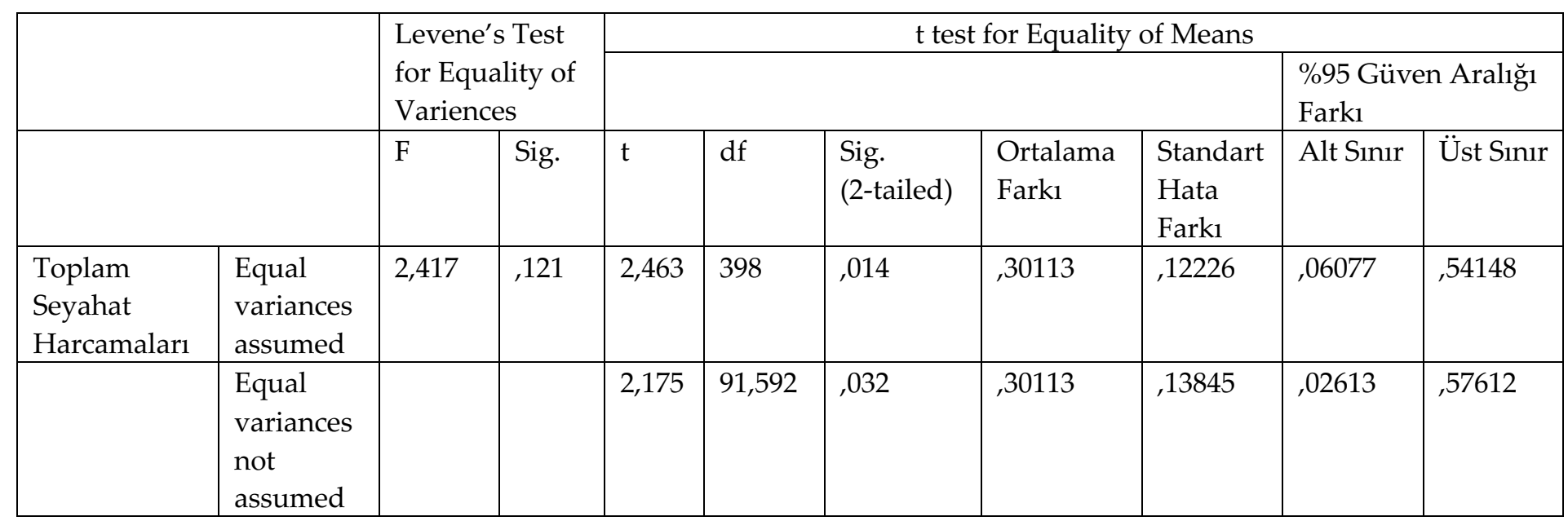

Levene's testine göre göre anlamlılık seviyesi 0,05 ' den büyük olduğundan iki grubun varyansları homojendir ( $\mathrm{p}$ değeri $=0,121$ ). Analiz sonucuna göre 71 cevaplayıcı parayı başka yerde harcamış olmayı tercih ederken $(2,1127) 329$ cevaplayıc ise parayı burada harcamış olmayı tercih etmiştir $(1,8116)$. Bağımsız iki örnek t-testi analizine göre grupların ortalamaları arasında fark olduğu gözlenmektedir. $\mathrm{P}$ değerinin 0,05 'den küçük olması ( $\mathrm{p}$ değeri $=0,014$ ) grupların ortalamaları arasında anlamlı bir fark olduğunu göstermektedir. Dolayısıyla sıfır (null) hipotezi reddedilerek, alternatif hipotez kabul edilmiştir. Bu durum karşılaştırılan gruplar arasında anlamlı fark olduğunu gösterir.

Bergama Antik Kenti'ni ziyaret eden turistlerin hane halkı gelirleri ile toplam seyahat harcamalarının ortalaması arasındaki fark analiz edilmiştir. Hane halkı gelir grupları ikiden fazla olduğu için Tek Yönlü Varyans Analizi (ANOVA)'nden yararlanılmıştır. Bu analizde hane halkı gelir düzeyleri arasında ortalama toplam seyahat harcamalarında bir fark olup olmadı̆̆ını incelemek üzere geliştirilen hipotez ise şöyledir:

$\mathrm{H}_{0}$ : Hane halkı gelir düzeyleri arasında toplam seyahat harcamalarının ortalamaları arasında anlamlı bir fark yoktur.

H5: Hane halkı gelir düzeyleri arasında toplam seyahat harcamalarının ortalamaları arasında anlamlı bir fark vardır.

Tablo 6. Varyansların Homejenliği Testi

\begin{tabular}{|l|c|c|c|c|}
\hline & Levene Statistic & df1 & df2 & Sig. \\
\hline Toplam Harcama & 1,723 & 7 & 392 &, 102 \\
\hline
\end{tabular}


Tablo 6'da Tek Yönlü ANOVA'nın temel varsayımı olan varyansların homojenliği testinin sonucu bulunmaktadır. Buradaki p değeri (Sig.) $0,05^{\prime}$ ten büyük olduğu için $(0,102)$ varyansların homojen olduğu görülmektedir. Sonuç olarak, varyans analizinin varsayımı sağlanmıştır.

Tablo 7. Varyans Analizi Tablosu (ANOVA) Toplam Harcama

\begin{tabular}{|l|l|l|l|l|l|}
\hline & Kareler Toplamı & df & $\begin{array}{l}\text { Ortalama } \\
\text { Kare }\end{array}$ & F & Sig. \\
\hline İlişkisiz Gruplar & 13,968 & 7 & 1,995 & 2,309 &, 026 \\
\hline İlişkili Gruplar & 338,742 & 392 &, 864 & & \\
\hline Toplam & 352,710 & 392 & & & \\
\hline
\end{tabular}

ANOVA tablosu toplam seyahat harcamalarının hane halkı gelir düzeyi grupları arasında bir farklılığın olup olmadığını test etmektedir. Tablodaki $\mathrm{F}$ değeri, $\mathrm{F}$ değerinin $\% 95$ anlamlılık düzeyindeki tablo değerinden büyükse $\mathrm{H}_{0}$ hipotezi reddedilir. Tablo sonuçlarına göre $\mathrm{p}$ değeri $(0,026)$ 0,05'den küçüktür. Hane halkı gelir düzey grupları arasında toplam seyahat harcamalarında farklılık olduğu bulunmuştur. Dolayısıyla sıfır (null) hipotezi reddedilerek, alternatif hipotez kabul edilmiş olur.

Tablo 8. (Post Hoc) Çoklu Karşılaştırma Testi

\begin{tabular}{|c|c|c|c|c|c|c|}
\hline \multirow{2}{*}{$\begin{array}{l}\text { (I)Hanehalkı } \\
\text { geliri }\end{array}$} & \multirow{2}{*}{$\begin{array}{l}\text { (J) Hanehalkı } \\
\text { geliri }\end{array}$} & \multirow{2}{*}{$\begin{array}{l}\text { Ortalama } \\
\text { Fark1 (I-J) }\end{array}$} & \multirow{2}{*}{$\begin{array}{l}\text { Standart } \\
\text { Hata }\end{array}$} & \multirow[t]{2}{*}{ Sig } & \multicolumn{2}{|c|}{ \%95 Güven Aralığ 1} \\
\hline & & & & & Alt Sinır & Üst Sinir \\
\hline \multirow{7}{*}{$\begin{array}{l}\text { Birinci Grup: } \\
\text { 1.501-3.000 TL }\end{array}$} & $3.001-4.500 \mathrm{TL}$ &,- 03106 & 22282 & 1,000 &,- 7101 & 6480 \\
\hline & $4.501-6.500 \mathrm{TL}$ &,- 34363 & 20625 & ,709 &,- 9722 & ,2849 \\
\hline & $6.501-9.500 \mathrm{TL}$ &,- 16740 & 18787 & ,987 &,- 7399 & 4051 \\
\hline & 9.501-19.000 TL &,- 35714 & 31198 & ,946 & $-1,3079$ & ,5936 \\
\hline & $19.001-28.500 \mathrm{TL}$ & $-1,05714^{*}$ & ,34246 & ,045 & $-2,1007$ &,- 0136 \\
\hline & $28.501-37.500 \mathrm{TL}$ &,- 62987 & 33079 &, 549 & $-1,6379$ & ,3782 \\
\hline & $\begin{array}{l}\text { 37.501 TL ve } \\
\text { daha fazlası }\end{array}$ &,- 31366 & 26160 & ,932 & $-1,1109$ & 4835 \\
\hline \multirow{7}{*}{$\begin{array}{l}\text { İkinci Grup: } \\
\text { 3.001-4.500 TL }\end{array}$} & $1.501-3.000 \mathrm{TL}$ & 0,3106 & ,22282 & 1,000 &,- 6480 & 7101 \\
\hline & 4.501-6.500 TL &,- 31257 & 17454 & 627 &,- 8445 & 2193 \\
\hline & $6.501-9.500 \mathrm{TL}$ &,- 13634 & , 15237 & ,986 &,- 6007 & 3280 \\
\hline & 9.501-19.000 TL &,- 32609 & 29199 & ,953 & $-1,2159$ & ,5637 \\
\hline & $19.001-28.500 \mathrm{TL}$ & $-1,02609^{*}$ & ,32434 & ,036 & $-2,0145$ &,- 0377 \\
\hline & $28.501-37.500 \mathrm{TL}$ &,- 59881 & 31200 & ,538 & $-1,5496$ & 3520 \\
\hline & $\begin{array}{l}\text { 37.501 TL ve } \\
\text { daha fazlası }\end{array}$ &,- 28261 & 23740 & ,934 & $-1,0060$ & 4408 \\
\hline \multirow{7}{*}{$\begin{array}{l}\text { Üçüncü Grup: } \\
\text { 19.001-28.500 TL }\end{array}$} & $1.501-3.000 \mathrm{TL}$ & $1,05714^{*}$ & ,34246 & ,045 & ,0136 & 2,1007 \\
\hline & 3.001-4.500 TL & $1,02609^{*}$ & ,32434 & ,036 & ,0377 & 2,0145 \\
\hline & $4.501-6.500 \mathrm{TL}$ & ,71351 & 31320 & 308 &,- 2409 & 1,6679 \\
\hline & $6.501-9.500 \mathrm{TL}$ & 88974 & 30141 & 065 &,- 0288 & 1,8082 \\
\hline & 9.501-19.000 TL & 70000 & 39101 & ,627 &,- 4915 & 1,8915 \\
\hline & $28.501-37.500 \mathrm{TL}$ & ,42727 & 40617 & ,966 &,- 8105 & 1,6650 \\
\hline & $\begin{array}{l}\text { 37.501 TL ve } \\
\text { daha fazlası }\end{array}$ & 74348 & 35211 & 409 &,- 3295 & 1,8165 \\
\hline
\end{tabular}

*Ortalama fark 0.05 düzeyinde anlamlıdır. 
Varyans analizi sonucunda gruplar arasında fark bulunduğundan, farklılığın hangi gruplardan kaynaklandığını tespit etmek için Post Hoc testlerinden Tukey testi uygulanmıştır. Tukey testi sonucunda ortalamaları arasında farklılık olan gruplar Tablo 8 üzerinde asteriks $\left(^{*}\right)$ imgeleri ile işaretlenmiştir. Yanlarında asteriks $\left(^{*}\right)$ imgesi olan grupların ortalamaları arasında 0,05 düzeyinde anlamlı fark bulunmaktadır. Bu sonuçlara göre;

- 19.001-28.500 TL arasında hane halkı geliri olan üçüncü grup, 1.501-3.000 TL arasında hane halkı geliri olan birinci gruba göre daha fazla toplam seyahat harcaması yapmıştır. Aralarındaki ortalama farkı 1,05714'tür ve anlamlılık düzeyi $(0,045) 0,05$ 'in altındadır.

- 19.001-28.500 TL arasında hane halkı geliri olan üçüncü grup, 3.000-4.500 TL arasında hane halkı geliri olan ikinci gruba göre daha fazla toplam seyahat harcaması yapmıştır. Aralarındaki ortalama fark 1,02609'dur ve anlamlılık düzeyi $(0,036)$ 0,05'in altındadır.

Bu bulgulara göre hane halkı geliri yüksek olan grupların daha düşük hane halkı gelirine sahip olanlardan daha fazla seyahat harcaması yaptığı sonucuna varılmıştır. Turizm olayının en temelinde insan öğesinin bulunması turist davranışlarının anlaşılmasını zorunlu kılar. Turizm hareketinin belirleyicisi olan turist, turizm olayının öznesi durumundadır. Turist, temel amacı psikolojik tatmin sağlamak olan, seyahati boyunca ekonomik kazanç elde etmeyi düşünmeyen fakat ekonomik anlamda tüketici olan turizm olayına katılacak şekilde gelire ve boş zamana sahip olan kişidir. Bu çalışmanın bulgularına göre de turizm olayına katılan kültür turistinin hane halkı gelirinin seyahat harcamalarında belirgin bir rol oynadığı görülmüştür. Çünkü, bu çalışmaya konu olan kültür turistlerinin seyahat harcamalarının hane halkı gelir gruplarına göre farklılık gösterdiği anlamlı olarak bulunmuştur. Bu çalışmanın bulguları, turizmin öznesi olan turistin hane halkı gelirinin seyahat harcamalarına ve dolayısıyla turizm gelirlerine olan etkisini de açıklamaktadır.

\section{SONUÇ ve ÖNERILER}

Turizm, küresel ekonominin en hızlı ve en büyük gelişme gösteren sektörlerinden biridir. Turizm, günümüzde önemli bir ekonomik etkinlik olarak görülmektedir. Turizmin meydana getirdiği ekonomik etkilerin birincisi ve en önemlisi hiç şüphesiz turizm gelirlerinden oluşmaktadır. Turizm gelirleri ise, turistin ziyaret ettiği bölgede yaptığı harcamalardan (ulaşım, konaklama, yiyecek-içecek, eğlence, alışveriş vb.) oluşmaktadır. Ülke ekonomileri için son derece önemli olan turizm gelirlerini artırmanın bir yolu da kişi başına turist harcamalarını artırmaktır. Bir turistin herhangi bir ülkede veya bölgede yaptığı turizm harcaması o ülkenin veya bölgenin gelir elde etmesi anlamına gelmektedir. Turizm ekonomisi alanında turist harcamalarının (harcama kalıplarının ve özelliklerinin) araştırılması çok önemli konular arasında yer almaktadır. $\mathrm{Bu}$ yüzden turizm ekonomisi açısından çok önem arz eden turist harcamaların belirleyen faktörleri tespit ederek, yerel ekonomiye en çok katkısı olan turizm tipinin ve turist profilinin belirlenmesinin sağlanması, yapılacak her türlü tanıtım ve planlama çalışmalarına yol gösterici olmaktadır. Bununla birlikte, turizm sektörünün daha başarılı olması için gereken kapsamlı planlama ve yönetimin daha etkin yapılabilmesi için turistlerin harcama kalıplarının ve özelliklerinin belirlenmesi bu anlamda çok önemlidir. Çünkü, ülkeler arasındaki turizm gelirleri arasındaki farklılıkların nedenlerinin araştırılmasında, o ülkede yapılan turizm harcamalarının ortaya konması çoğunlukla gündeme gelmektedir. Bu çerçevede çalışmada turist harcamaları arasındaki farklılıkların araştırılması amaçlanmıştır. Turist harcamaları arasındaki farklılıkların araştırılmasında çalışma alanı olarak Bergama Antik Kenti seçilmiştir. Bergama Antik Kenti'nin çalışma alanı olarak seçilmesinin en önemli nedeni UNESCO Dünya Miras Listesi'nde bulunması ve yerli ve yabancı kültür turistleri için çeşitli çekiciliklerinin varlığıdır. 
Çalışmada öncelikle turist harcamalarını belirleyen değişkenler ve kullanılan analiz yöntemleri tespit edilmeye çalışılmıştır. Literatür incelendiğinde bağımsız değişkenlerin dört ana kategoride gruplandığı görülmüştür. Bunlar; sosyo-ekonomik (Agarwal ve Yochum, 1999; Nicolau ve Mas, 2005; Zheng ve Zhang, 2011; Hung vd., 2012; Garcia-Sanchez vd., 2013; Marrocu vd., 2015; Tavares vd., 2015; Topbaş ve Uğuz, 2017; Daşkıran ve Özkoç, 2019), sosyo-demografik (Jang vd., 2004; Nicolau ve Mas, 2005; Hung vd., 2012; Marrocu vd., 2015; Serra ve Rodrigues, 2015; Jurdana ve Frleta, 2016; Topbaş ve Uğuz, 2017; Daşkıran ve Özkoç, 2019), seyahatle ilgili (Agarwal ve Yochum, 1999; Seiler vd., 2003; Jang vd., 2004; Nicolau ve Mas, 2005; Garcia-Sanchez vd., 2013; Marrocu vd., 2015; Tavares vd., 2015; Jurdana ve Frleta, 2016) ve psiko-grafik (Oppermann, 1996; Nicolau ve Mas, 2005; Garcia-Sanchez vd., 2013; Marrocu vd., 2015; Serra ve Rodrigues, 2015; Tavares vd., 2015) değişkenlerdir. Bu faktörler turist harcamalarının belirleyicileridir. Turistin harcama davranışı üzerinde etkili olan bu faktörleri belirlemek ve etkisini ölçmek turizmden elde edilen geliri artırmak için çok önemlidir. Bu amaçla, çalışmada kültür turistlerinin sosyoekonomik (gelir), sosyo-demografik (cinsiyet, uyruk), seyahat ile ilgili (seyahatte başkalarının masrafını karşılayıp karşılamadıkları) ve psiko-grafik (parayı başka yerde harcamayı isteyip istemedikleri) değişkenlerinin toplam seyahat harcamalarının ortalamaları arasında anlamlı bir fark olup olmadığını analiz etmek için çeşitli hipotezler geliştirilmiştir. Literatürde, turist harcamaları ile bağımsız değişkenler arasındaki ilişkinin analizinde kullanılan yöntemler oldukça farklılık göstermektedir. İki bağımsız grup arasındaki seyahat harcama farklılıklarını araştırdığı çalışmasında Oppermann (1996) hipotezlerin testinde iki örnek t-testi kullanmıştır. Bu çalışmada da bağımsız grupların toplam seyahat harcamaları arasındaki farklılıkların analizinde iki örnek t-testi kullanmıştır. Hipotez testi sonuçlarına göre bağımsız örnek gruplarının toplam seyahat harcama ortalamaları arasında anlamlı farklılık olduğu bulunmuştur.

Toplam seyahat harcamaları; cinsiyete göre incelendiğinde erkekler kadınlardan daha fazla seyahat harcaması yapmıştır. Turistlerin yerli ve yabancı oluşuna göre incelendiğinde, yabancı turistlerin yerli turistlere göre daha fazla harcama yaptığı görülmektedir. Turistlerin seyahatte başkalarının masrafını karşılayıp karşılamadıklarına göre incelendiğinde, masraf karşılayanların daha fazla harcama yaptıkları görülmektedir. Turistlerin parayı başka yerde harcamayı isteyip istemedikleri incelendiğinde parayı başka yerde harcamak isteyenler daha fazla harcama yapmışlardır. Turistler arasındaki gelir farklılıkları ve bu farklılı̆̆ın turist harcamalarına yansımasının önemi vurgulandığından bu çalışmada da turistlerin hane halkı gelirleri ile toplam seyahat harcamalarının ortalamaları arasındaki farklılığın tespit edilmesi amaçlanmıştır. Turistlerin hane halkı geliri incelendiğinde hane halkı geliri üçüncü grup olanların hane halkı geliri birinci ve ikinci grup olanlara göre daha fazla harcama yapmıştır. Bu bulgular diğer çalışmalar ile birlikte değerlendirildiğinde özellikle gelir değişkeninin (Dardis vd., 1994; Agarwal ve Yochum, 1999; Nicolau ve Mas, 2005; Zheng ve Zhang, 2011; Garcia-Sanchez vd., 2013; Jurdana ve Frelata, 2016; Topbaş ve Uğuz, 2017; Daşkıran ve Özkoç, 2019) turist ve seyahat harcamaları üzerinde oldukça etkili olduğu görülmektedir. Bu bakımdan ülkelerin turizm gelirlerine olumlu etkisi olan turist harcamalarındaki artış özellikle bireylerin veya hane halkının geliri ile doğrudan ilişkilidir. Özellikle azgelişmiş ülkelerin kişi başına düşen milli geliri yüksek olan turistleri ülkeye ve turistik bölgelere akışını sağlamaları şiddetle önerilmektedir. Ülkelerin gelişmişlik göstergelerinden biri olan kişi başına düşen milli gelir, turizm hareketliliğinin de belirgin bir değişkeni durumundadır. Bu bakımdan özellikle azgelişmiş ülkelerin ekonomik büyümesinde önemli payı olan turizm gelirlerinin artışı ancak turist harcamaları ile gerçekleşebilmektedir. Bu çalışmanın ve diğer çalışmaların sonuçları irdelendiğinde özelikle gelirin turist ve seyahat harcamalarında en etkin faktör olduğu görülmektedir. Çalışmanın sonucunda azgelişmiş ülkelerin turizm gelirlerini artırması için özellikle gelişmiş ülkelerin bireylerini cezbedecek turistik ürün sunmaları önerilmektedir. Sonuç olarak yapılması gereken, ülkelerin turizm 
gelirlerini artırmaya yönelik çalışmaların içinde turist harcamalarını iyi analiz ederek ekonomik anlamda ülkeye bir katma değer sağlayacak stratejilerin geliştirilmesi önerilmektedir.

\section{KAYNAKÇA}

Agarwal, V. B. and Yochum, G. R. (1999). Tourist Spending and Race of Visitors, Journal of Travel Research, 38(2): 173-176.

Albayrak, A. (2013). Alternatif Turizm, Ankara: Detay Yayincllk.

Brida, J. G. and Scuderi, R. (2012). Determinants of Tourist Expenditure: A Review of Microeconometric Models, Munich Personal RePEc Archive (MPRA), 30 April 2012, Munich, Germany.

Dardis, R., Soberon-Ferrer, H. and Patro, D. (1994). Analysis of Leisure Expenditures in the United States, Journal of Leisure Research, 26(4): 309-321.

Daşkıran, F. ve Özkoç, H. H. (2019). Türkiye'deki Hane halkının Tatil Harcama Yapısının İncelenmesi: Tobit Model, Elektronik Sosyal Bilimler Dergisi, 71(18): 1051-1065.

Frechtling, D. C. (1994). Assessing the Impacts of Travel and Tourism Introduction to Travel Economic Impact Estimation, (Eds.) Ritchie, J.R.B. and Goeldner, C.R.: Travel Tourism and Hospitality Research: A Handbook for Managers and Researchers, $2^{\text {nd }}$ edition, In (pp. 359-365), New York: John Wiley \& Sons.

Garcia-Sanchez, A., Fernandez-Rubio, E. and Collado, M. D. (2013). Daily Expenses of Foreign Tourists, Length of Stay and Activities: Evidence from Spain, Tourism Economics, 19(3): 613-630.

Haberal, H. (2011). Yaylacılık Kültürünün Yayla Turizmi İçindeki Önemi: Rize Yaylaları Örneği, Yüksek Lisans Tezi, Gazi Üniversitesi, Ankara.

Hayta, A. B. (2008). Turizm Pazarlamasında Tüketici Satın Alma Süreci ve Karşılaşılan Sorunlar, Kastamonu Ĕ̆itim Dergisi, 16(1): 31-48.

Hausmann, A. (2007). Cultural Tourism: Marketing Challenges and Opportunities for German Cultural Heritage, International Journal of Heritage Studies, 2(13): 170-184.

https://berto.org.tr/wp-content/uploads/2020/07/Y1l-2019-95.Faaliyet-Raporu.pdf [Erişim Tarihi: 17.05.2020].

http://www.tuik.gov.tr/PreTablo.do?alt_id=1072 [Erişim Tarihi: 19.05.2020)

https://www.e-unwto.org/doi/pdf/10.18111/9789284421152 [Erişim Tarihi: 22.05.2020].

Hung, W. T., Shang, J. K. and Wang, F. C. (2012). Another Look at The Determinants of Tourism Expenditure, Annals of Tourism Research, 39(1): 495-498.

Jang, S., Bai, B., Hong, G., and O'Leary, T. J. (2004). Understanding Travel Expenditure Patterns: A Study of Japanese Pleasure Travelers to The United States by Income Level, Tourism Management, 3(25): 331-341. 
Jurdana, D. S. and Frleta, D. S. (2016). Factors Affecting the Expenditure of Domestic and Foreign Tourists: The Evidence from Rijeka and Opatija, Croatia, 23 ${ }^{\text {rd }}$ Biennial International Congress, Tourism \& Hospitality Industry, Trends and Challenges, 28-29 April 2016, Opatija, Croatia.

Kalaycı, Ş. (2018). SPSS Uygulamalı Çok Değişkenli İstatistik Teknikleri. Ankara: Dinamik Akademi.

Legoherel, P. and Wong, K. K. F. (2006). Market Segmentation in the Tourism Industry and Consumers' Spending: What About Direct Expenditures?, Journal of Travel and Tourism Marketing, 20(2): 15-30.

Marrocu, E., Paci, R. and Zara, A. (2015). Micro-Economic Determinants of Tourist Expenditure: A Quantile Regression Approach, Tourism Management, 50: 13-30.

Nicolau, J. L. and Mas, F. J. (2005). Heckit Modelling of Tourist Expenditure: Evidence from Spain, International Journal of Service Industry Management, 16(3): 271-293.

Oppermann M. (1996). Visitation of Tourism Attractions and Tourist Expenditure Patterns: Repeat Versus First-Time Visitors, Asia Pacific Journal of Tourism Research, 1(1): 61-68.

Özdamar, M. (2011). Şanlıurfa'da Kültür Turizmi: Şanlıurfa'ya Kültür Turizmi Kapsamında Seyahat Acentaları ile Gelen Yerli Turistlerin Profilini ve Anlık Satın Alma Davranışlarını Belirlemeye Yönelik Bir Araştırma, Yüksek Lisans Tezi, Mersin Üniversitesi, Mersin.

Özdemir, Y. A, Şahin Tekin, S. T. ve Esin, A. A. (2015). Çözümlü Örneklerle Örnekleme Yöntemine Giriş. Ankara: Seçkin Kitabevi.

Seiler, V. L., Hsieh, S., Seiler, M. J. and Hsieh, C. (2003). Modeling Travel Expenditures for Taiwanese Tourism, Journal of Travel \& Tourism Marketing, 13(4): 47-60.

Serra, J., Correia, A. and Rodrigues, P. M. M., (2015). Tourist Spending Dynamics in the Algarve: A Cross-sectional Analysis, Tourism Economics, 21(3): 475-500.

Silberberg, T. (1995). Cultural Tourism and Business Opportunities for Museums and Heritage Sites, Tourism Management, 16(5): 361-365.

Tavares, J. M., Ivanov, S. and Neves, O. V. (2015). Determinant of Tourists' Spending During Tours: The Case of Repeat vs. First-Time Visitors to State Minas Gerais, Brazil, Tourism Planning and Development, 13 (1): 23-36.

Topbaş, F. ve Uğuz Çelik, S. (2017). Turist Harcamalarının Belirleyicileri Üzerine Bir Yatay Kesit Analiz, EconWorld2017@Rome Proceedings, Rome, Italy.

Uygur, S. E. ve Baykan, E. (2007). Kültür Turizmi ve Turizmin Kültürel Varlıklar Üzerindeki Etkileri, Ticaret ve Turizm Ĕgitim Fakültesi Dergisi, 2: 30-49.

Wu, L., Zhang, J., and Fujiwara, A. (2013) Tourism Participation and Expenditure Behaviour: Analysis Using a Scobit Based Discrete-continuous Choice Model, Annals of Tourism Research, 40(1): 1-17. 
Zheng. B. and Zhang, Y. (2011). Household Expenditures for Leisure Tourism in the USA, 1996 and 2006, International Journal of Tourism Research, 15(2): 197-208. 